\title{
Analysis of eggplant (Solanum melongena)-related germplasm: morphological and AFLP data contribute to phylogenetic interpretations and germplasm utilization
}

Received: 13 February 2003 / Accepted: 12 August 2003 / Published online: 16 October 2003

(C) Springer-Verlag 2003

\begin{abstract}
A total of 94 Solanum accessions, including eggplants and related species, were morphologically characterized based on greenhouse observations, and molecularly analysed by the AFLP technique. Morphological parameters were helpful in assessing similarities or differences among accessions, and molecular data were used to support morphological conclusions. A dendrogram was computed based on the Dice genetic distances using the neighbour-joining method. The analysis was efficient in the assignment of a species name for eight out of nine accessions that were not previously classified, and revealed that 14 further accessions were misnamed in the collection originally received. The results indicate that the taxonomy of Solanum sections and subgenera including several species should be reconsidered. The AFLP technique was revealed as an efficient tool in determining genetic relationships among species. In general, morphological observations were consistent with molecular data, indicating that both approaches complemented to define the phylogenetic status of a large genus like Solanum. In terms of eggplant breeding, the molecular analysis of the Melongena complex, and of the other sections of the subgenus Leptostemonum, establishes useful germplasm relationships in the gene pool available for the genetic improvement of the cultivated species. The results we have provided highlight an urgent necessity to include molecular parameters in handling and characterizing the genebank-deposited germplasm related to cultivated crops.
\end{abstract}

Communicated by F. Salamini

A. Furini $(\bullet)$

Department of Science and Technology,

University of Verona, Strada Le Grazie 15, 37134 Verona, Italy

e-mail: antonella.furini@univr.it

Tel.: +39-45-8027950

Fax: +39-45-8027929

J. Wunder

Max-Planck-Institut für Züchtungsforschung,

Carl-von-Linne-Weg 10, 50829 Köln, Germany

\section{Introduction}

Several economically important species such as eggplant, potato, tomato, tobacco and pepper belong to the Solanaceae family. At the beginning of the 20th century, G. Bitter, amongst others studied the Solanaceae, focusing on the largest genus Solanum (Daunay et al. 2001). Other taxonomists have also contributed to the characterization of this genus, considering particular characters of taxonomic significance (e.g. Correll 1962; Seithe and Anderson 1982; Whalen 1984; Bohs 1999). The vast amount of available literature has, however, led to a considerable confusion surrounding the genus, for which 1,000 to 1,400 Solanum species have been associated to more than 3,000 binomial names (Daunay and Lester 1988).

Solanum melongena L., the cultivated Brinjal eggplant, was originally described by Linnaeus (1753) who considered plants cultivated in Asia, Africa and America. A large number of cultivars are known and characterized by their variability in morphology (growth habit and plant vigour, hairness and prickliness), physiology (earliness of flowering, water need and uptake) and biochemical features such as bitterness of fruit (Daunay et al. 1991). India or Indochina represent the centre of eggplant diversity (Vavilov 1951; Lester and Hasan 1991), but the affinities of eggplant (S. melongena) to related species remain uncertain. Taxa that are morphologically similar to eggplant are difficult to classify (Karihaloo and Gottlieb 1995), and the delimitation of the cultivated eggplant from the weedy forms Solanum insanum and its wild progenitor Solanum incanum is unclear (Lester and Hasan 1990). It is also recognized that $S$. incanum taxa described for Indian lines are distinct from those from Africa and the Middle East (Lester and Hasan 1991). Furthermore, Lester and Hasan (1991) noted that both $S$. melongena and $S$. incanum have been frequently confused with the less closely related Scarlet eggplant Solanum aethiopicum L., the Gboma eggplant Solanum macrocarpon L. and with other wild species.

The taxonomic confusion in the eggplant complex is due to the fact that phylogenetic relationships among taxa 
have been established, considering mainly morphological features, crossability and $F_{1}$ fertility (Baksh 1979; Lester and Hasan 1991). These parameters are, however, insufficient for establishing genetic affinities, because $S$. melongena can be crossed not only to putative progenitors but also to more distantly related species (Daunay et al. 1991). Moreover, because of the existence of a high morphological variability, morphological data can lead to ambiguous interpretations. To overcome these problems, isozyme variation has been considered (Lester and Hasan 1991; Karihaloo and Gottlieb 1995) but little has been done, so far, to assess the genetic relationships within the eggplant complex using molecular markers. At the DNA level, genetic affinities have been reported based on the analysis of chloroplast DNA (Sakata et al. 1991; Sakata and Lester 1994; Isshki et al. 1998); RAPD analysis (Karihaloo et al. 1995) has also been used to compare cultivated S. melongena and the weedy S. insanum, and more recently (Mace et al. 1999) to follow the variation of AFLP patterns in cultivated eggplant and wild relatives. Conflicts, however, have arisen, when only molecular data have been considered. These data are of help when morphological analyses are insufficient (Patterson et al. 1993), as in the case of the genus Solanum which includes so many species. It is, in fact, now evident for this genus that polymorphisms detected at the molecular level have the potential to identify accessions and to assign them to the correct species (Rodriguez et al. 1999).

Molecular markers are also useful in population biology. Until recently, it was difficult to demonstrate speciation in the absence of geographical isolation. Today, those phenomena can be approached based on molecular phylogeny, and the current use of molecular techniques in genetic diversity studies is supported by the finding that evolutionary processes such as natural selection and genetic drift produce divergent phylogenetic branchings which can be recognized because the molecular sequences on which they are based share a common ancestor (Page and Holmes 1998).

The accessions analysed in this study were obtained from the USDA Plant Genetic Resources Conservation Unit (University of Georgia, Griffin, GA, USA). Unfortunately, movement of accessions from one environment to another often creates confusion with respect to their historical or geographical derivation. Thus, while the analysis of accessions derived from different geographical areas is central to the study of genetic diversity, it may happen that a given diverse geographic origin of two accessions cannot be considered as a parameter describing genetically different materials (Skroch et al. 1998). Ultimately, only phenotypic and genetic criteria are, together, the parameters to be adopted for the study of genetic relationships. Our objectives were: (1) to describe the genetic similarity between accessions and confirm them using morphological parameters; (2) to identify duplicated accessions, if any, among the species received; (3) to describe and to assign to specific taxa, nine accessions of Solanum that were not previously classified; (4) to assess genetic distances among wild and domes- ticated forms of some taxa, and (5) to detect the AFLP variation among the $S$. melongena and related species of the genus Solanum. This study highlights an urgent necessity to include molecular parameters in the handling and characterizing of genebank-deposited germplasm related to cultivated crops.

\section{Materials and methods}

\section{Plant material}

A total of 94 Solanum accessions from the USDA Plant Genetic Resources Conservation Unit (Georgia, USA) were included in the present analysis. Among the accessions received as S. melongena and $S$. aethiopicum, a set was chosen to cover a wide range of geographical origins and to maximise genetic diversity. Nine accessions included in this analysis were unclassified (details in Table 1)

\section{DNA isolation}

Three seeds for each accession were germinated and genomic DNA was extracted from $0.5 \mathrm{~g}$ of the freeze-dried leaf sample using the QIAGEN DNeasy Plant Mini Kit (QIAGEN GmbH, Max-VolmerStrasse 4, 40724 Hilden, Germany).

\section{AFLP analysis}

The AFLP procedure was performed essentially as described by Zabeau and Vos (1993) and Vos et al. (1995). A total of five primer combinations were used to amplify EcoRI- and MseI-digested DNA. Primer combinations, and EcoRI and MseI adapters, are reported in Table 2. DNA $(0.5 \mu \mathrm{g})$ was restricted for $2 \mathrm{~h}$ using EcoRI ( $5 \mathrm{U}), M s e \mathrm{I}(5 \mathrm{U})$ and $5 \mu \mathrm{l}$ of $10 \times$ restriction-ligation buffer (100 mM of Tris $\mathrm{HCl}, 100 \mathrm{mM}$ of $\mathrm{MgAc}, 500 \mathrm{mM}$ of Kac) in a final volume of $50 \mu \mathrm{l}$. The adapter ligation was performed by adding the following to the restricted genomic DNA: EcoRI-adapter (5 pMol), MseI-adapter (50 pMol), ATP (10 mM), T4-DNA ligase (1 U), 10x restriction-ligation buffer $(1 \mu \mathrm{l})$, and $\mathrm{H}_{2} \mathrm{O}$ to reach a final volume of $60 \mu \mathrm{l}$. The reaction was incubated at $37^{\circ} \mathrm{C}$ for $5 \mathrm{~h}$. Preamplification was carried out by mixing digested and ligated DNA $(1 \mu \mathrm{l})$ with EcoRI primer + 1 selective nucleotide $(75 \mathrm{ng}), \mathrm{Mse}$ I primer +1 selective nucleotide $(75 \mathrm{ng})$, dNTPs $(2 \mathrm{mM}), 10 \times$ PCR buffer $(2.5 \mu \mathrm{l}), \mathrm{Taq}$ DNA polymerase (1 U) in a total volume of $25 \mu \mathrm{l}$. The PCR reaction was performed for 20 cycles at $92^{\circ} \mathrm{C} / 60 \mathrm{~s}$, annealing at $60^{\circ} \mathrm{C} / 30 \mathrm{~s}$ and extention at $72^{\circ} \mathrm{C} / 60 \mathrm{~s}$, followed by a $72^{\circ} \mathrm{C} / 5 \mathrm{~min}$ extention. Only the EcoRI primer was labeled and sufficient primer was prepared for 100 selective amplifications by mixing $\gamma-\left[{ }^{33} \mathrm{P}\right]$ $\operatorname{ATP}(5 \mu \mathrm{l}, 100 \mu \mathrm{Ci} / \mu \mathrm{l})$, T4-kinase buffer $(2.5 \mu \mathrm{l})$, T4-kinase (5 U), $5 \mu \mathrm{l}$ of EcoRI primer $+3(50 \mathrm{ng} / \mu \mathrm{l})$ and $12 \mu \mathrm{l}$ of $\mathrm{H}_{2} \mathrm{O}$ in a final volume of $25 \mu \mathrm{l}$. The reaction was performed at $37^{\circ} \mathrm{C}$ for $30 \mathrm{~min}$ followed by $10 \mathrm{~min}$ at $70^{\circ} \mathrm{C}$ to inactivate the T4-kinase. The final PCR amplification was carried out in a final volume of $10 \mu \mathrm{l}$ with a $\left.{ }^{[3} \mathrm{P}\right]$-labelled EcoRI primer, three nucleotides and an unlabelled MseI primer and three nucleotides with a profile of $94^{\circ} \mathrm{C} / 30 \mathrm{~s}$, $65^{\circ} \mathrm{C} / 30 \mathrm{~s}, 72^{\circ} \mathrm{C} / 60 \mathrm{~s}$ for 1 cycle, followed by $94^{\circ} \mathrm{C} / 30 \mathrm{~s}, 56^{\circ} \mathrm{C} / 60 \mathrm{~s}$, $72^{\circ} \mathrm{C} / 60 \mathrm{~s}$ for 24 cycles. PCR products were resolved on a $5 \%$ denaturing polyacrylamide gel by loading $2 \mu \mathrm{l}$ of the PCR sample per track. Gels were fixed in $10 \%$ acetic acid for $30 \mathrm{~min}$, then dried at $80^{\circ} \mathrm{C}$ for $2 \mathrm{~h}$ and exposed to X-ray film for 24 to $48 \mathrm{~h}$ depending on signal intensity.

\section{Data analysis}

Only distinct, well-resolved fragments were scored, discarding faint bands. We analysed the AFLP banding patterns as dominant 
Table 1 Accessions of eggplant and related species examined, taxonomically defined as received, and with species names reassigned or newly classified with seed source and the native distributional range

\begin{tabular}{|c|c|c|c|c|c|c|}
\hline $\begin{array}{l}\text { Entry } \\
\text { no. }\end{array}$ & $\begin{array}{l}\text { Accession } \\
\text { no. }\end{array}$ & $\begin{array}{l}\text { Species: } \\
\text { assigned name }\end{array}$ & $\begin{array}{l}\text { Species: } \\
\text { re-assigned name } \\
\text { (or newly }_{\text {classified taxon) }^{\mathrm{a}}}\end{array}$ & $\begin{array}{l}\text { Subgenus, } \\
\text { and Section }^{\mathrm{c}}\end{array}$ & Seed source & Native distributional range \\
\hline 1 & PI 368425 & S. pseudocapsicum & & Sol., Ps., & Yugoslavia & Probably of neotropic origin \\
\hline 2 & PI 304600 & S. nigrum & & Sol., Sol., & Japan & $\begin{array}{l}\text { Algeria, Marocco, Tunisia; } \\
\text { temperate and tropical Asia }\end{array}$ \\
\hline 3 & PI 390820 & S. ochrantum & & Pot., Pet., & Peru & $\begin{array}{l}\text { South America: from Ecuador } \\
\text { to Peru }\end{array}$ \\
\hline 4 & PI 203339 & Solanum suaveolens & & Pot., Bas., & Mexico & $\begin{array}{l}\text { North America: Mexico; } \\
\text { South America: } \\
\text { from Belize to Venezuela }\end{array}$ \\
\hline 5 & PI 265884 & S. suaveolens & & & South America & Guatemale, Peru \\
\hline 6 & PI 390819 & S. suaveolens & & & Peru & \\
\hline 7 & PI 473478 & S. suaveolens & & & Peru & \\
\hline 8 & PI 243342 & S. caripense & & Pot., Bas., & Costa Rica & $\begin{array}{l}\text { Â South America: } \\
\text { from Colombia to Peru }\end{array}$ \\
\hline 9 & PI 280049 & S. aviculare & S. laciniatum & Arch., Arch., & Minnesota & $\begin{array}{l}\text { Australia: South Wales, Tasmania, } \\
\text { Victoria (S. laciniatum)** }\end{array}$ \\
\hline 10 & PI 420414 & S. aviculare & S. laciniatum & & Spain & \\
\hline 11 & PI 337284 & S. laciniatum & & & Hungary & \\
\hline 12 & PI 337310 & S. laciniatum & & & New Zeland & \\
\hline 13 & PI 504520 & S. laciniatum & & & Australia & \\
\hline 14 & PI 358311 & S. sisymbriifolium & & Lept., ${ }^{*}$ Cryp., ${ }^{*}$ & India & $\begin{array}{l}\text { South America: } \\
\text { from Argentina to Brazil }\end{array}$ \\
\hline 15 & PI 381291 & S. sisymbriifolium & & & India & \\
\hline 16 & PI 420997 & S. rostratum & & Lept., Andr., ${ }^{*}$ & Netherlands & $\begin{array}{l}\text { North America: } \\
\text { United States and Mexico }\end{array}$ \\
\hline 17 & PI 487467 & S. sessiliflorum & & Lept., Las., & Venezuela & $\begin{array}{l}\text { South America: } \\
\text { from Venezuela to Brasil }\end{array}$ \\
\hline 18 & PI 487464 & S. stramonifolium & & & Venezuela & $\begin{array}{l}\text { from Ecuador to Northern } \\
\text { Amazon Basin }\end{array}$ \\
\hline 19 & PI 308877 & S. aculeatissimum & S. viarum & Lept., Ac., & India & $\begin{array}{l}\text { Eastern Brazil to Northeastern } \\
\text { Argentina }(S . \text { viarum })^{* *}\end{array}$ \\
\hline 20 & PI 312108 & S. aculeatissimum & S. viarum & & India & \\
\hline 21 & PI 305325 & S. acerifolium & S. atropurpureum & Lept., Ac., & Colombia & $\begin{array}{l}\text { South America: from Argentina } \\
\text { to Brazil (S.atropurpureum)** }\end{array}$ \\
\hline 22 & PI 305320 & S. atropurpureum & & & Colombia & \\
\hline 23 & PI 390818 & S. spinosissimum & S. capsicoides & Lept., Ac., & Peru & $\begin{array}{l}\text { Caribbean Islands, Atlantic } \\
\text { coast of Brazil throughout } \\
\text { the tropics }(S . \text { capsicoides })^{* *}\end{array}$ \\
\hline 24 & PI 183949 & S. capsicoides & S. viarum & & India & \\
\hline 25 & PI 196300 & S. capsicoides & & & Nicaragua & \\
\hline 26 & PI 370043 & S. capsicoides & & & India & \\
\hline 27 & PI 245968 & S. mammosum & & Lept., ${ }^{*}$ Ac., ${ }^{*}$ & Mexico & $\begin{array}{l}\text { North America: Mexico; } \\
\text { South America: from Barbados } \\
\text { to Brazil }\end{array}$ \\
\hline 28 & PI 305323 & S. mammosum & & & Colombia & \\
\hline 29 & PI 247828 & S. americanum & S. aethiopicum & Lept., Ol., & Congo & $\begin{array}{l}\text { Central Africa: from Ivory } \\
\text { Coast to Kenya and Tanzania } \\
\text { (S. aethiopicum)** }\end{array}$ \\
\hline 30 & PI 194166 & S. aethiopicum & & & Yugoslavia & \\
\hline 31 & PI 420230 & S. aethiopicum & & & Africa & \\
\hline 32 & PI 424860 & S. aethiopicum & & & Brazil & \\
\hline 33 & PI 441848 & S. aethiopicum & & & Brazil & \\
\hline 34 & PI 441859 & S. aethiopicum & & & Brazil & \\
\hline 35 & PI 441893 & S. aethiopicum & & & Brazil & \\
\hline 36 & PI 441851 & S. aethiopicum & & & Brazil & \\
\hline 37 & PI 441891 & S. aethiopicum & & & Brazil & \\
\hline 38 & PI 179745 & S. anguivi & S. incanum & Mel., Lept., & India & $\begin{array}{l}\text { Africa: Egypt, Ethiopia, Sudan; } \\
\text { Asia: Iran, Iraq, Israel, Jordan, } \\
\text { Saudi Arabia, Turkey, }\end{array}$ \\
\hline 39 & PI 180485 & S. anguivi & S.incanum & & India & Lebanon, Turkey $(S \text {. incanum })^{* *}$ \\
\hline 40 & PI 183357 & S. anguivi & S.incanum & & India & \\
\hline 41 & PI 381155 & S. incanum & & & India & \\
\hline 42 & PI 200854 & S. ferox & S. incanum & & Myanmar & \\
\hline 43 & Grif 1260 & S. melongena & & Mel., Lept., & Thailand & $\begin{array}{l}\text { India, South-East Asia, } \\
\text { South China }\end{array}$ \\
\hline
\end{tabular}


Table 1 (continued)

\begin{tabular}{|c|c|c|c|c|c|c|}
\hline $\begin{array}{l}\text { Entry } \\
\text { no. }\end{array}$ & $\begin{array}{l}\text { Accession } \\
\text { no. }\end{array}$ & $\begin{array}{l}\text { Species: } \\
\text { assigned name }\end{array}$ & $\begin{array}{l}\text { Species: } \\
\text { re-assigned name } \\
\text { (or newly } \\
\text { classified taxon) }{ }^{\mathrm{a}}\end{array}$ & $\begin{array}{l}\text { Subgenus, } \\
\text { and Section }^{\mathrm{c}}\end{array}$ & Seed source & Native distributional range \\
\hline
\end{tabular}

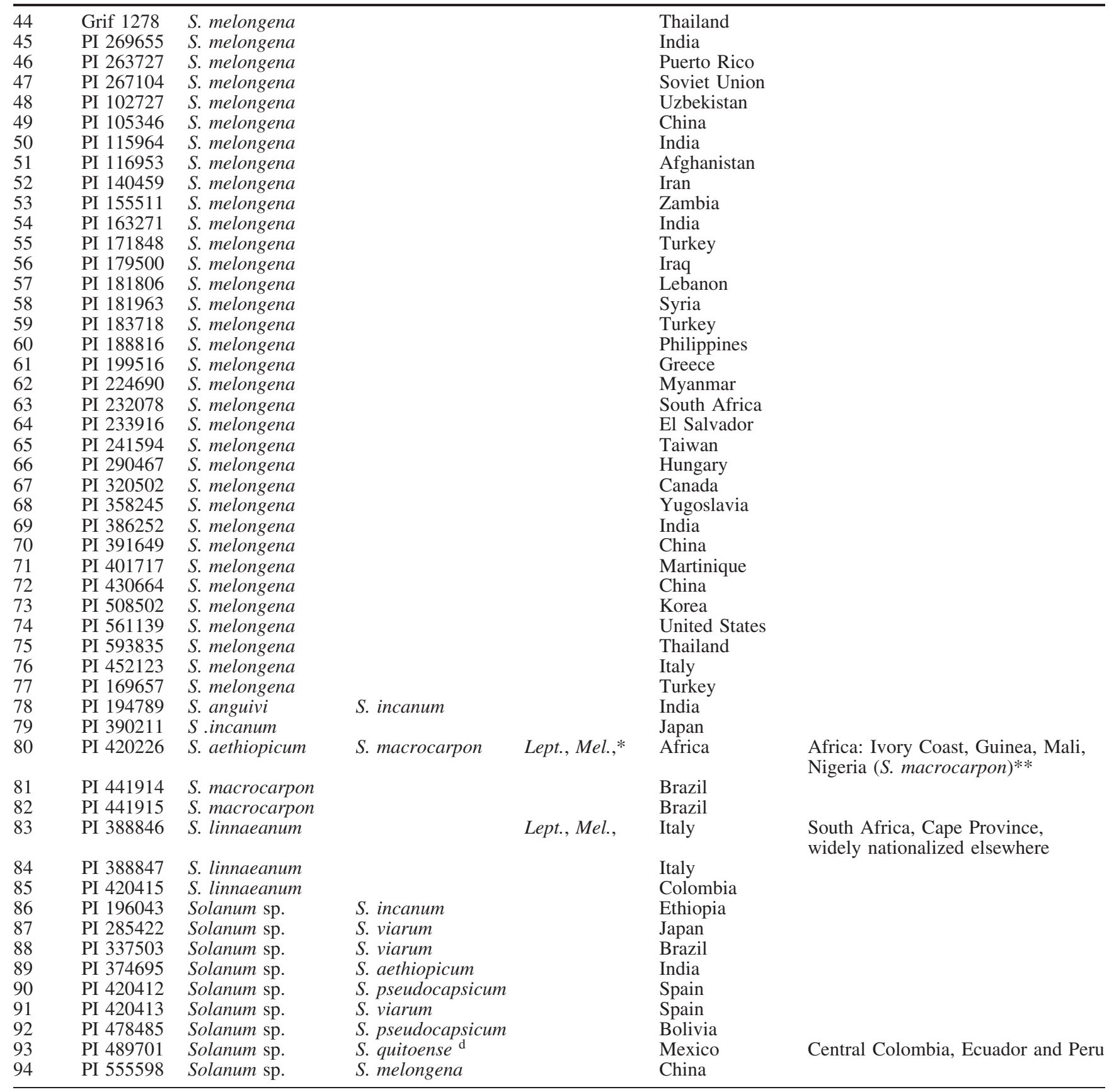

* According to this work these sections and subgenera should be reconsidered

** Native distributional range is referred to the newly classified taxon

${ }^{\text {a }}$ Based on results of this work

b Arch = Archeosolanum, Lept $=$ Leptostemonum, Pot $=$ Potatoe, Sol $=$ Solanum

c Ac = Acanthophora, Andr = Androceras, Arch = Archeosolanum, Bas = Basarthum, Cryp =Cryptocarpum, Las = Lasiocarpa, Mel = Melongena, $\mathrm{Ol}=$ Oliganthes, Pet $=$ Petota,$P s=$ Pseudocapsicum, Sol $=$ Solanum

d $S$. quitoense (genebank observation) 
Table 2 Enzymes and primers used in AFLP analysis

\begin{tabular}{lll}
\hline Enzyme & Type & Sequence $\left(5^{\prime}-3^{\prime}\right)$ \\
\hline EcoRI & Adapter & CTCGTAGACTGCGTACC \\
CTGACGCATGGTTAA \\
Mse I & Adapter & GACGATGAGTCTGAG \\
& TACTCAGGACTCAT \\
EcoRI & Primer+3 & GACTGCGTACCAATTCAGC \\
MseI & Primer+3 & GATGAGTCCTGATAAAGC \\
EcoRI & Primer+3 & GACTGCGTACCAATCAGT \\
Mse I & Primer+3 & GATGAGTCCTGAGTAAACT \\
EcoRI & Primer+3 & GACTGCGTACCAATCAGC \\
MseI & Primer+3 & GATGAGTCCTGAGTAATC \\
EcoRI & Primer+3 & GACTGCGTACCAATTCAGT \\
$M s e I$ & Primer+3 & GATGAGTCCTGAGTAAAGC \\
EcoRI & Primer+3 & GACTGCGTACCAATCAGT \\
Mse I & Primer+3 & GATGAGTCCTGAGTAAACT \\
\hline
\end{tabular}

markers and assumed that, for each primer, bands of the same size (homologous bands) represent the same DNA sequence (Bachmann 1997) and are alleles of a single biallelic locus (Lynch and Milligan 1994). The amplified fragments were scored in terms of presence (1) or absence (0) of homologous bands and a matrix of the different AFLP patterns was assembled. For the analysis of similarity between the accessions, the distance-matrix approach (Weir 1996) was used. First, a pairwise distance matrix was computed according to Nei and Li (1979) based on the Dice'ssimilarity coefficient (Dice 1945). Second, a dendrogram was created using the neighbour-joining (NJ) algorithm (Saitou and Nei 1987; Studier and Keppler 1988). To measure the reliability of the branching patterns, and thus the quality of the resulting phylogenetic groups, the original matrix was bootstrapped 500 times (Felsenstein 1985). The bootstrap-values of the main groups are shown at the corresponding nodes. All calculations were performed using the program TREECON (Vers 1.3b, Van De Peer and Wachter 1994)

\section{Results}

\section{Morphology}

The 94 accessions considered in this study were grown in the greenhouse. Plants were maintained until seed set and observed for their morphological traits. The same plants were the source of DNA for molecular characterization. Considering the type of plant development and parameters such as leaf shape, presence or absence of spines, flower colour and habit, fruit colour and shape, and comparison among accessions, it was concluded that several species were misidentified (Table 1). The morphological characterization and comparison of PI 2800499 and PI 420414-10, previously identified as Solanum aviculare, with the accessions PI 337284-11, PI 33731012 and PI 504520-13, received as Solanum laciniatum, indicated that their phenotypes were very peculiar and indistinguishable among them. They were semi-woody shrubs, with a wide range of leaf form on the same plant, with pinnately lobed leaves on young plants and a decrease in lobing with flowering. Identical purple flowers with emarginate corolla indicated that all the five accessions should be kept under the name of $S$. laciniatum (Fig. 1a). In this case, as well as in others, morphological consideration were important for the reassignment of names to accessions, but also the molecular evidence, presented in the next section of results, was considered.

The accessions PI 305325-21 and PI 305320-22 were both collected in Colombia and were originally classified respectively as Solanum acerifolium and Solanum atropurpureum. Their identical morphology suggested that the two accessions could belong to the same species. They were fast-growing shrubs with reflexed slender spines on the stem, and flowering throughout the year in the greenhouse and with 10 to 20 flowers per inflorescence. The large, highly pinnatified and undulated leaves indicated that both accessions belong to $S$. atropurpureum, probably the most prickly species of the Acanthophora section (Fig. 1b, c).

Other accessions included in the same Acanthophora section showed a high morphological similarity when observed in the greenhouse; PI 308877-19 and PI 31210820, classified as Solanum aculeatissimum and collected in India, were phenotypically indistinguishable from the accessions PI 183949-24, PI 19630025 and PI 370043-26. The latter were collected in India and Nicaragua, respectively, and received as Solanum capsicoides, while the accession PI 390818-23 was collected in Peru and named Solanum spinosissimum. All these plants were small prickly shrubs with a range of leaf forms from pinnatified, with few lobes to ovate or petiolate with toothed leaf blades and spines on the upper and lower leaf surfaces along the main veins. In this group of accessions, the flowers were in clusters and remote from the leaves with the corolla greenish-white and stelliform with lanceolate lobes. Fruits were round, smooth, 2 to $4 \mathrm{~cm}$ in diameter, striated light green on green when immature, and orange when mature for PI 308877-19, PI 312108-20 and PI 183949-24, and orange-red for the accessions PI 390818-23, PI 196300-25 and PI 370043-26. The high morphological similarity among these accessions made it difficult to understand whether the same species was reported under different names, or if different species were so closely related to make it impossible to distinguish them on the basis of morphological features. The careful consideration of the seed shape of the six accessions helped to distinguish between them. The accessions PI 390818-23, PI 196300-25 and PI 37004326 had seeds with a flattened, papery margin, which may assign them to $S$. capsicoides, a species morphologically similar to Solanum viarum. PI 308877-19, PI 312108-20 and PI 183949-24, all collected in India, had seeds more similar to those of other Solanum species, supporting the possibility that they belong to $S$. viarum (Fig. 1d). Moreover, the two accessions PI 308877-19 and PI 312108-20, received as $S$. aculeatissimum, have been previously classified as Solanum khasianum which is reported to be a synonym for $S$. viarum (Daunay et al. 1991). The accessions PI 245968-27 and PI 305323-28, collected respectively from Mexico and Colombia, were identified as Solanum mammosum. Vegetatively, they are very similar to accessions of $S$. capsicoides and S. viarum, but with flowers with a lavender corolla and fruits very 

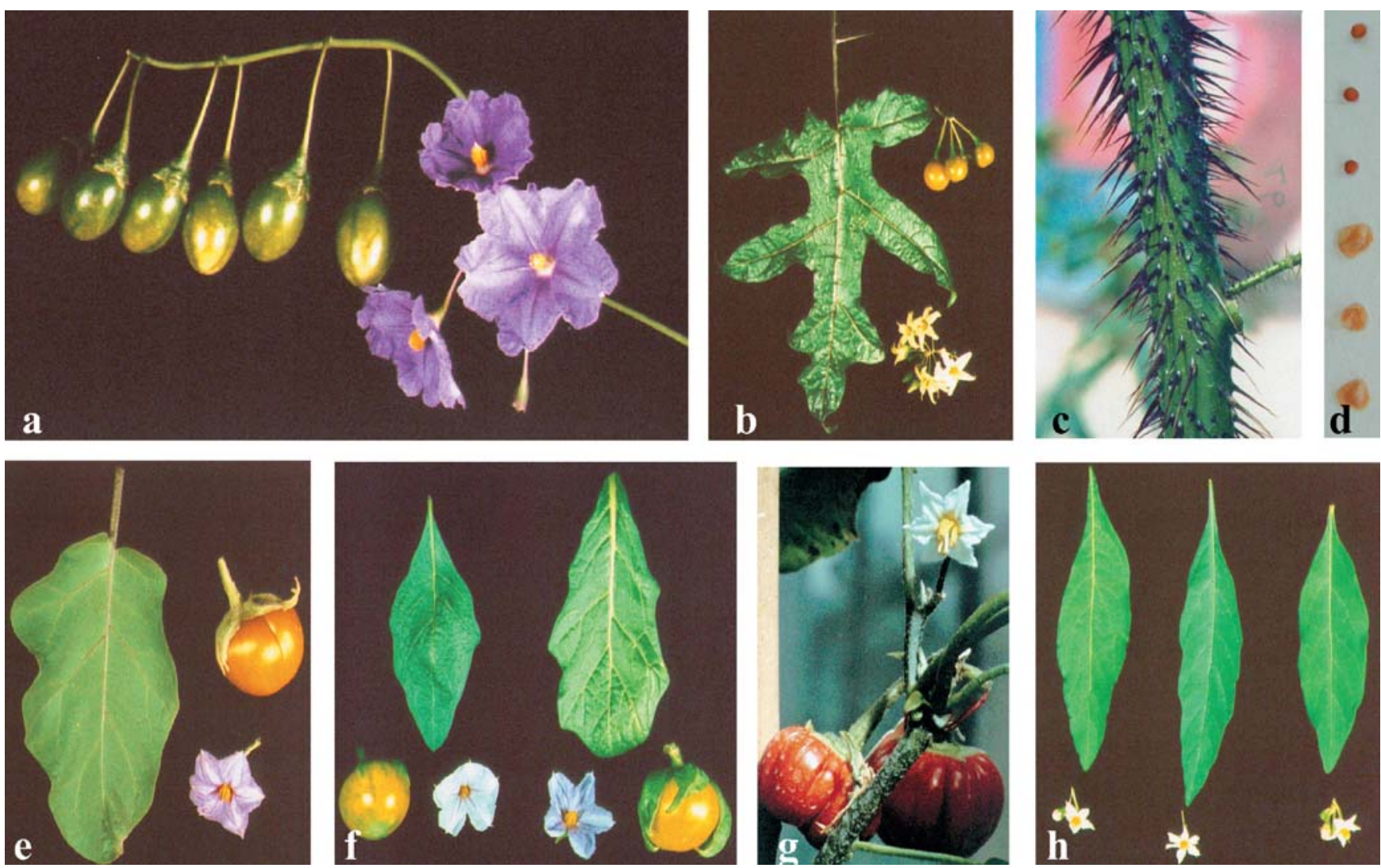

Fig. 1a-h Morphological details of several species considered in this study. a Flowers and fruits of S. laciniatum (PI 280049-9). b Leaf, flowers and fruit of $S$. atropurpureum (PI 305320-22). c $S$. atropurpureum stem. d Seeds (lower) of S. capsicoides (PI 39081823, PI 196300-25 and PI 370043-26); seeds (upper) of $S$. viarum (PI 308877-19, PI 312108-20 and PI 183949-24). e Leaf, flower and

distinct from those of species of the Acanthophora section. Fruits were large and unique in having protuberances at the base.

Accessions classified as Solanum sessiliflorum (PI 487467-17) and Solanum stramonifolium (PI 487464-18) according to the literature (Whalen et al. 1981; Whalen and Caruso 1983) should belong to the Lasiocarpa section and, when analysed, appeared morphologically distinct. $S$. stramonifolium was a lignescent shrub with a spiny stem and prickly and broadly ovate leaves, that showed only light pubescence and purplish colour on the lower surface. Fruits were about 10 to 15 per inflorescence and orange at maturity. S. sessiliflorum also showed a lignescent habit but with a pubescent stem and with very large, hairy and repand leaves. The inflorescence had 5 to 10 greenishwhite flowers, with the corolla divided into lanceolate lobes. This species produced large and globose berries, orange at maturity.

PI 390820-3 according to the genebank assignment, was a Solanum ochrantum representative which was distinct from all other accessions considered and did not show similarity with accessions of the subgenus Potatoe. fruit of S. incanum (PI 200854-42). f Leaves, flowers and fruits of S. macrocarpon (PI 420226-80 left and PI 441915-82 right). g Flowers and fruits of S. aethiopicum (PI 247828-29). h Leaves and flowers of $S$. pseudocapsicum (from left to right: PI 368425-1, PI 420412-90 and PI 478485-92)

Among the taxa analysed, an accession of Solanum nigrum (PI 304600-2), collected in Japan, was easily recognized because of its black ripe fruits.

A group of four accessions (PI 179745-38, PI 18048539, PI 183357-40 and PI 194789-78), all collected in India, were received as Solanum anguivi which is the recognised wild progenitor of S. aethiopicum (Lester 1986). A simple observation of these plants indicated that they were misclassified. All of them were, in fact, to be included in the Melongena complex. To this complex were also assigned PI 381155-41 and PI 390211-79 received as $S$. incanum, as well as PI 200854-42, that was incorrectly named Solanum ferox (Fig. 1e). Among the nine accessions designed as Solanum sp. PI 196043-86 and PI 555598-94 were candidates to be included into the eggplant complex based on morphology. The group of accessions included in this complex were very distinct from all others. In fact, although the morphological investigations indicated a wide diversity in vegetative, floral and fruit characters, their overall morphology allowed them to be clustered into the eggplant aggregate. Plants varied from 1 to $2 \mathrm{~m}$ in height, were unarmed to 
moderately prickly, with di-foliate sympodia, and sinuated-marginated pubescent leaves. Flower habit varied from flowers borne singly or in clusters with a white, lavender or purple stelliform corolla. We observed globose, oval or elongate berries, often green in immature fruits, yellow, white, white with purple stripes or purple with a fleshy pericarp when mature. While based on several traits, all these accessions clearly belonged to the eggplant complex. In some lines, it was possible, nevertheless, to recognize clear wild species characters (frequent presence of spines, small flowers and berries). A correct reclassification should refer the wild forms to $S$. incanum, the wild progenitor of $S$. melongena. The remaining taxa represented different genotypes of $S$. melongena and its feral forms (molecular data are in favor of this interpretation; see later). A more detailed distinction in morphological groups for the species of the eggplant cluster was beyond the aim of this work (see also the Discussion).

From the S. aethiopicum accessions, based on morphology, PI 420226-80 was reclassified as Solanum macrocarpon, a domesticated species with edible fruits and leaves, cultivated throughout a large part of Africa and with identical morphology to PI 441914-81 and PI 441915-82, received as $S$. macrocarpon (Fig. 1f). A further accession of $S$. aethiopicum was easily spotted among the genotypes analyzed because of the white stelliform corolla and scarlet fruits: PI 247828-29 was erroneously named Solanum americanum (Fig. 1g). A distinct phenotype was observed for the three accessions of Solanum linnaeanum (PI 338846-83, PI 388847-84 and PI 420415-85). They were woody plants with a deeply lobed and prickled leaves, with purple flowers with striated green immature fruits that became yellow at maturity. Morphologically this species appeared definitely quite distant from others of the Melongena complex.

The morphology of other unclassified species (Solanum spp.) allowed the assignement of PI 285422-87, PI 337503-88 and PI 420413-91 to Solanum viarum. The white stelliform corolla and red globose berries that were observed for PI 374695-89 indicated its similarity to $S$. aethiopicum, while PI 420412-90 and PI 478485-92 were to be recognized as Solanum pseudocapsicum based on plant habit, on lanceolate leaves and on the white small flowers with prominent yellow-orange anthers (Fig. 1h), and on their colourful fruits. One accession (PI 489701), according to the genebank description was reported as Solanum quitoense. By observations in the greenhouse it was possible to establish a certain degree of similarity for this line with PI 487467-17, classified as S. sessiliflorum.

\section{Molecular fingerprints}

The AFLP analysis, carried out on all accessions morphologically characterized, produced a large number of distinct fragments for each primer pair used in PCR amplification. Six primer combinations allowed the scoring of 300 amplification products and the results of the analysis indicated the absence of identical accessions in the collection. Molecular fingerprinting based on AFLP markers was introduced to support the correct assignment of accessions to eggplant-related Solanum species, for all cases where morphological discrepancies were noted. In addition, the fingerprints were the basis for the analysis of the relationships among the species considered. Morphological observations already allowed a preliminary classification of a yet unnamed Solanum sp., while accessions misidentified were assigned to presumed correct taxa based on morphological data. Furthermore, when morphological and molecular data were compared, several greenhouse observations were revealed, consistent with the molecular analysis. For instance, PI 280049-9 and PI 420414-10, originally classified as S. aviculare, the cluster according to the taxa to which they were assigned by morphological analysis, with accessions of $S$. laciniatum. Thus, molecular data fully support the phenotypical observations (Fig. 2).

Accessions of $S$. capsicoides and $S$. viarum, that were misclassified or sent as Solanum sp. and morphologically only distinguishable based on seed characters, fell into two distinct but closely related clusters: $S$. capsicoides and $S$. viarum. Even PI 390818-23, erroneously named $S$. spinosissimum but recognized as $S$. capsicoides by plant morphology and seed shape, was shown to belong to the S. capsicoides group by DNA analysis. Thus, while in these cases seed morphology was the only discriminating character, molecular markers were efficient in separating these taxa. AFLP data indicated that PI 305325-21, misnamed as $S$. acerifolium, was in fact $S$. atropurpureum and that the two accessions of $S$. atropurpureum, although morphologically different from $S$. capsicoides and $S$. viarum, had an intermediate topology between the two clusters. Molecular results were in full agreement with morphological observations for the accessions identified, according to the genebank, as $S$. anguivi and S. ferox which had to be moved to the Melongena complex based on morphological observations in the greenhouse. Moreover, PI 180485-39, PI 183357-40, PI 179745-38 and PI 194789-78, erroneously sent as $S$. anguvi, were indeed accessions of $S$. incanum. This is the progenitor of $S$. melongena and all such lines we have studied cluster together with PI 200854-42, PI 390211-79, PI 381155-41 and PI 196043-86. In the enlarged part of the dendrogram describing the Melongena complex (left in Fig. 2), a clear separation of the wild $S$. incanum from the cultivated forms of S. melongena was evident. Similarly, molecular marker results were consistent with the phenotypic classification of the accession PI 420226-80 moved to the $S$. macrocarpon group by greenhouse observation and of PI 247828-29 that was unambiguously assigned by morphology to $S$. aethiopicum.

Assignment of species identity to unclassified Solanum sp. accessions

Out of the nine unclassified accessions considered, eight were easily identified by morphology and the assignments 
Fig. 2 Unrooted neighbourjoining tree based on AFLP data using pairwise genetic similarities according to Dice (1945). Upper left: enlargement of the $S$. melongena branch showing cultivated forms and wild progenitors. Numbers at the end of the branches correspond to accessions reported in Table 1. Bootstrap-values are reported at the base of the branches. Question marks indicate that sections and subgenera have to be reconsidered

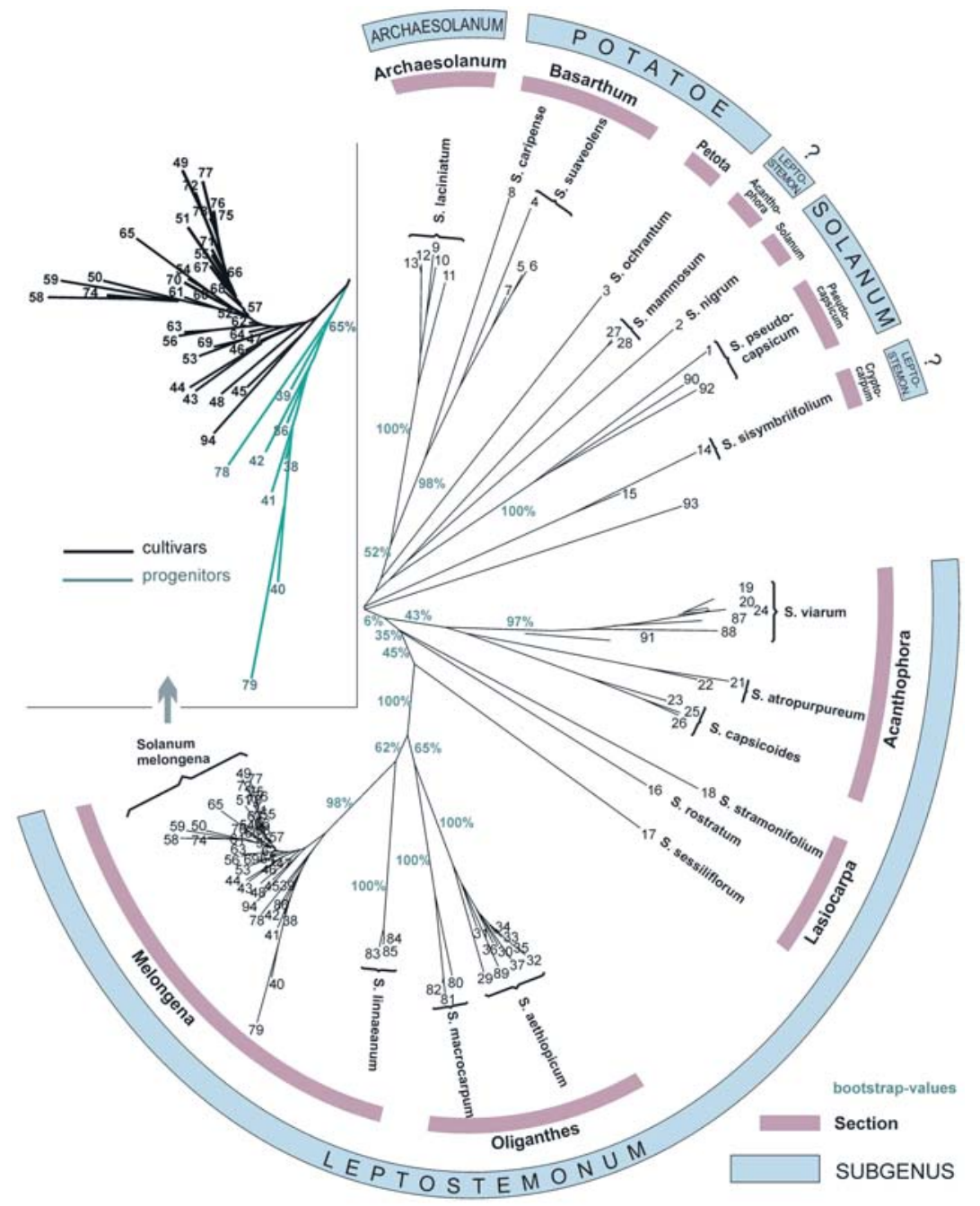

were confirmed by AFLP data. As indicated in Fig. 2, PI 420412-90 and PI 478485-92 were S. pseudocapsicum accessions, PI 374695-89 was molecularly included into the $S$. aethiopicum group, while PI 285422-87, PI 33750388 and PI 420413-91 fell into the $S$. viarum group. The accession PI 196043-86, as already indicated, was included in the S. incanum branch, while the PI 55559894 clustered within the $S$. melongena aggregate. PI 489701-93, although showing phenotypic similarity with S. sessiliflorum and received as a possible $S$. quitoense, did not cluster with other Lasiocarpa taxa: in this case, morphological and molecular characterization did not provide a conclusive species identification.

Considerations of subgenera, sections and species within Solanum

Among the sections considered in this study, several are included in the subgenus Leptostemonum. These sections are Melongena, Oliganthes, Lasiocarpa and Acanthopho$r a$. The unrooted tree also indicates that $S$. linnaeanum belongs to the section Melongena with an intermediate position between sections Melongena and Oliganthes. On the contrary, the three accessions of $S$. macrocarpon considered should be excluded from section Melongena, and placed in section Oliganthes. They turned out to be closely related to $S$. aethiopicum.

The results of this analysis also showed that $S$. stramonifolium and $S$. sessiliflorum were isolated lines within section Lasiocarpa, and, unexpectedly, that Solanum rostratum (sect. Androceras) appeared close to $S$. stramonifolium; however as only one accession of $S$. rostratum was available, and as the grouping of this part of the tree is weak (low bootstrap values), it is difficult to draw any firm conclusions about the status of this taxon. Moreover, the AFLP analysis divided section Acanthophora into two clusters: while $S$. capsicoides, $S$. viarum and $S$. atropurpureum formed a cluster, the two accessions of $S$. mammosum (PI 245968-27 and PI 305323-28), easily recognized by the fruit shape, were separated. Its position between the subgenera Potatoe and Solanum is not supported by high bootstrap values, thus it may be positioned elsewhere as well. The subgenus Solanum included, as expected, sections Pseudocapsicum and Solanum. Also, the accessions of Solanum sisymbri- 
ifolium (section Cryptocarpum) showed no affiliation with the subgenus Leptostemonum. It should be noted that the accession PI 489701-93 received as a Solanum sp. but suspected to be a $S$. quitoense line, showed morphological similarity with $S$. sessiliflorum but did not cluster with the other Lasiocarpa accessions.

\section{Wild and domesticated forms}

In Fig. 2, all accessions that belong to the eggplant complex are grouped in defined clusters and separated from all other taxa. In this $S$. melongena group it was possible to recognize branches indicating that some accessions are more genetically related to each other. Accessions left unclassified or misidentified but recognized, based on morphological features, as part of the eggplant group, were indeed included in this cluster. The polymorphism observed within the eggplant group (Fig. 2 enlargement) indicates that among these accessions, besides cultivated $S$. melongena and wild progenitors, weedy forms are included. It is worth noting that most eggplant accessions considered here were collected in Asian countries which represent the center of greatest eggplant diversity. Considering domesticated species of eggplants (S. melongena, S. aethiopicum and S. macrocarpon), only the wild forms of $S$. melongena were present in our analysis.

\section{Discussion}

The great abundance of Solanum species represents nearly $1 \%$ of the world's angiosperm flora (Whalen and Caruso 1983). On the basis of biogeographic evidence, a Cretaceous origin for Solanum has been postulated (Hawkes and Smith 1965), and further studies (Gottlieb 1977) confirmed that the genus Solanum is actually quite ancient. The extreme diversity of species belonging to Solanum may then be attributable to its great antiquity, but in addition to an extraordinary rate of speciation (Whalen 1979). The subgenus Leptostemonum accounts for about 33\% of the Solanum taxa (D'Arcy 1991) but phylogenetic analyses for this subgenus, have been mainly deduced so far from morphological characters, crossability and serological studies (Lester and Hasan 1991). Biosystematic and evolutionary studies have for long time, and for the most part, considered the morphological features of the mature organism (Hammond 1979). Thus, a considerable portion of Solanum taxonomy has been based on inflorescence and flower type, and vegetative structures such as leaf shape, lobing, disposition were on the axis of fully developed leaves. Nee (1979) observed that many species of the subgenus Leptostemonum show great variation in leaf shape: young vigorous branches tend to have large and highly lobed leaves, while flowering branches may have small entire leaves. Taxonomic incongruences may thus arise due to the fact that some characters show this type of phenotypic plasticity (Whalen 1984).

Discontinuous markers (RFLPs, RAPDs, AFLPs and SNPs) can provide a measure of genetic distances to establish phylogenetic relationships among taxa (Karihaloo et al. 1995; Aggarwal et al. 1999; Rodriguez et al. 1999; El Rabey et al. 2002). In biosystematic studies of Solanum section Petota, Kardolous et al. (1998) proved that molecular markers such as AFLPs are more informative and reliable than morphological markers. In the same study, it has been reported that the AFLP technique is suitable at the intraspecific level, while the interspecific phylogenies might be less reliable due to an increasing chance of the co-migration of non-homologous DNA fragments. Recent results using AFLP markers to align genetic maps from different potato genotypes (Rouppe van der Voort et al. 1997), and to study Hordeum taxa (El Rabey et al. 2002), proved that co-migration of bands defines similarity due to ancestry also at an interspecific level. In this study the combined use of morphological and AFLP data made possible: (1) the establishment of a genetic distance between accessions; (2) the reclassification of several taxa that were previously misidentified; (3) the new classification of eight out of nine Solanum sp. that were not previously named; (4) the distinction among domesticated and wild forms of eggplants, and (5) the confirmation or exclusion of several taxa from sections and subgenera.

The eggplant aggregate showed a very large morphological variation, to some extent reflected in the unrooted tree based on AFLP data. The results reported here are not aligned with those obtained by Karihaloo and Gottlieb (1995) and by Karihaloo et al. (1995), who studied eggplants by allozyme and by RAPD analysis, respectively. These authors observed little genetic polymorphism among the genotypes studied and suggested the existence of a very small gene pool from which the cultivated forms arose. The migration of S. incanum, or of its derivative wild ancestor of $S$. melongena from Africa into Asia, either carried by man or by sea currents (Lester and Hasan 1991) may explain the narrow genetic bases of $S$. melongena. There might be two explanations for the high degree of variation observed in this study. First, our analysis of DNA variability has been based on AFLP markers which proved to be more informative than RAPD markers and allozymes; second, most of the accessions of the eggplant group analysed here derive from Asian countries where the greatest diversity is found. Our results indicate that while all members of the eggplant aggregate cluster together, enough genomic flexibility has been created within the group to adapt to changes in the environment. A high degree of variation has been detected, by using the AFLP technique, for the $S$. melongena group $\mathrm{E}$ that is reported to be a weedy relative of the cultivated eggplant and for the S. incanum group C (Mace et al. 1999).

The recent literature on genetic relationships among $S$. melongena and the closely related Solanum species revealed by allozyme, cpDNA restriction sites and other 
variation revealed by discontinuous markers, has never included S. linnaeanum (Isshiki et al. 1994; Sakata and Lester 1994; Karihaloo et al. 1995; Isshiki et al. 1998; Mace et al. 1999; Karihaloo et al. 2002). It is interesting to note that AFLP fingerprinting indicates that the eggplant group seems to be more closely related to $S$. linnaeanum than to $S$. macrocarpon and to $S$. aethiopicum, two other forms of cultivated eggplants.

Almost all work done considering morphology and hybridization experiments has included $S$. macrocarpon in the section Melongena. The recent seed protein study by Karihaloo et al. (2002), supports the placement of $S$. macrocarpon outside the eggplant complex. When taxonomic affinities were investigated using chloroplast DNA analysis (Sakata et al. 1991), it was concluded that $S$. macrocarpon should be excluded from section Melonge$n a$. The more refined work of Mace et al. (1999) based on the AFLP technique, indicated that the correct placement of $S$. macrocarpon within the section Melongena is uncertain. The results presented in this paper are consistent with the findings of Sakata et al. (1991), Mace et al. (1999) and Karihaloo et al. (2002): S. macrocarpon has to be excluded from the section Melongena and is more related to $S$. aethiopicum (section Oliganthes) than to $S$. melongena. Moreover, the fact that $S$. macrocarpon and $S$. aethiopicum are domesticated and cultivated mainly in Africa, supports their relatively similar topology in the dendrogram.

Results of this work indicate that $S$. sessiliflorum PI 487467-17 and S. stramonifolium PI 487464-18 might be phylogenetically isolated, and represent taxa of the section Lasiocarpa, while Solanum sp. PI 489701-93 is excluded from this section. For these species, phylogenetic affinities have been so far been determined by using morphological characters (Whalen et al. 1981) or allozymes (Whalen and Caruso 1983) and more recently by considering the crossability between $S$. quitoense, $S$. stramonifolium and other species of the section Lasiocarpa (Heiser and Anderson 1999; Heiser 2001). Although the hybridization among species of the section Lasiocarpa is reported to be successful, Whalen et al. (1981) in a study based on morphological characters reported that in several respects $S$. stramonifolium and $S$. sessiliflorum are phylogenetically very different. Based on allozyme analysis (Whalen and Caruso 1983), four phylogenetic clades were reported for the section Lasiocarpa: (1) S. stramonifolium; (2) S. sessiliflorum; (3) Solanum hyporhodium, Solanum vestissimum and Solanum felinum and (4) Solanum candidum, Solanum lasiocarpum, S. quitoense, Solanum hirtum and Solanum pseudolulo. The available data in the present work support the species divergence observed for this section: the three species considered may represent well and early differentiated phylogenetic lines.

In our molecular analysis $S$. rostratum PI 420997-16 was unexpectedly positioned close to $S$. stramonifolium. This might indicate, as suggested by Dehmer (2001), that while morphological characters are controlled by a restricted part of the genome, the AFLP system can screen the whole genome, and support the view that morphological data must be, when possible, integrated with molecular results. However, since only one accession of $S$. rostratum was present in this study, it cannot be excluded that our conclusion will be challenged in the future.

The taxonomic complexity of the large and variable group of species associated with the section Solanum is generally accepted (Edmonds 1979; Dehmer 2001). In the AFLP analysis, the $S$. mammosum taxa appear close to $S$. nigrum within the section Solanum, which does not support the inclusion of $S$. mammosum in the section Acanthophora, subgenus Leptostemonum, as was previously reported (Nee 1991). The AFLP molecular analysis indicate clearly that the two accessions of $S$. mammosum are distinct from other species of the section Acanthopho$r a$, and the section and subgenus for this species should be reassigned. The systematic relationships of $S$. mammosum and of other species of the section Acanthophora have been assessed based on morphological variation, and $S$. mammosum is known particularly for its bizarre fruit which is very different from others of the genus Solanum. It is furthermore known that $S$. mammosum has $\mathrm{n}=11$ (Madhavadian 1968; Heiser 1971), whereas $n=12$ is the haploid number of chromosomes found in almost all species of the section Leptostemonum. In reviewing the biogeography of section Acanthophora, Nee concluded in 1979 that further work on the genetics of S. mammosum should be rewarding. More than 20 years later, our findings based on AFLP analysis can only support these conclusions. In the same biogeographic study, those species whose seeds are encircled by a flattened wing were included in this section and, since this trait is unique in Solanum, a monophyletic origin for them was supposed. Our results are in agreement with that observation: the accessions of $S$. capsicoides and $S$. viarum are morphologically very similar and can be distinguished by observing the seed shape, while $S$. atropurpureum accessions, phenotypically distinct from the others, also produce seeds with a papery margin: the molecular data indicate that $S$. atropurpureum and $S$. capsicoides might be monophyletic.

The molecular results again reinforce the possibility that the DNA variation may procede at a different rate compared to the divergence of morphological traits, supporting the need to incorporate morphological data and molecular analysis in taxonomical studies. In this respect, it is clear that our data indicate that the placement of S. sisymbriifolium within the section Criptocarpum subgenus Leptostemonum is also uncertain. It is already known that when species of the subgenus Leptostemonum are crossed with $S$. melongena, S. sysimbriifolium $\times S$. melongena do not produce hybrids. Further molecular studies on the section Cryptocarpum are needed but the position of $S$. sysimbriifolium within the subgenus Leptostemonum seems not to be justifiable.

In terms of eggplant breeding, hybridization experiments show that $S$. melongena is crossable with several species of the section Melongena, as well as with species 
of Oliganthes and, to a certain degree, also with species of other sections (Daunay et al. 2001). Even when the hybrids are partially or completely sterile, their existence indicates some degree of genetic relationship. All these species represent the natural gene pool available for the genetic improvement of the cultivated eggplant. For example, in S. linnaeanum, the resistance to Verticillium wilt and to salinity (Daunay et al. 1991) is reported. Thus, specific traits should be investigated in the wild species and they may be introgressed by sexual crossing or by somatic hybridization into commercial varieties of $S$. melongena. The three cultivated eggplants $S$. melongena, S. macrocarpon and S. aethiopicum are interfertile, with their wild progenitors representing the primary gene pool for genetic improvement and serving as a secondary gene pool, although they are moderately fertile. Many other species of Solanum may constitute the tertiary gene pool, and molecular tools applied to these Solanum species represent an extremely useful approach to assess the degree of relationship among them and to assist the process of gene introgression. Ultimately, as indicated in this work, molecular data combined with morphological characterization are highly suitable for clarifying the phylogenetic affinities of the large and complex genus Solanum.

Acknowledgements The authors thank Ms. S. Effgen for technical assistance and Dr. R. Schäfer-Pregl for advice on analysis. They are particularly grateful to Dr. R.N. Lester for his help in identifying misclassified and unclassified accessions.

\section{References}

Aggarwal RK, Brar DS, Nandi S, Huang H, Khush GS (1999) Phylogenetic relationship among Oryza species revealed by AFLP markers. Theor Appl Genet 98:1320-1328

Bachmann K (1997) Nuclear DNA markers in plant biosystematic research. Opera Bot 132:137-148

Baksh S (1979) Cytogenetic studies of the $F_{1}$ hybrid of Solanum incanum L. $\times$ S. melongena L. Variety "Giant of Benares". Euphytica 28:793-800

Bohs L (1999) Cyphomandra (Solanaceae). Flora Neotropica Monograph 63. New York Botanical Garden

Correll DS (1962) The potato and its wild relatives. Contribution of Texas Research Foundation, Bot Studies 4:1-606

D'Arcy WG (1991) The Solanaceae since 1976, with a review of its biogeography. In: Hawkes JG, Lester RN, Nee M, Estrada N (eds) Solanaceae III: taxonomy-chemistry-evolution. Royal Botanical Gardens Kew, London, pp 75-138

Daunay MC, Lester RN (1988) The usefulness of taxonomy for Solanaceae breeders, with special reference to the genus Solanum and to Solanum melongena L. (eggplant). Capsicum Newslett 7:70-79

Daunay MC, Lester RN, Laterrot H (1991) The use of wild species for the genetic improvement of Brinjal egg-plant (Solanum melongena) and tomato (Lycopersicum esculentum). In: Hawkes JG, Lester RN, Nee M, Estrada N (eds) Solanaceae III: taxonomy-chemistry-evolution. Royal Botanical Gardens Kew, London, pp 389-412

Daunay MC, Lester RN, Gebhardt C, Hennart JW, Jahn M, Frary A, Doganlar S (2001) Genetic resources of eggplant (Solanum melongena) and allied species: a new challenge for molecular geneticists and eggplant breeders. In: van den Berg RG, Barendse GWM, van der Weerden GM, Mariani C (eds)
Solanaceae V: advances in taxonomy and utilization. Nijmegen University Press, pp 251-274

Dehmer KJ (2001) Conclusions on the taxonomy of the Solanum nigrum complex by molecular analyses of IPK germplasm accessions. In: van den Berg RG, Barendse GWM, van der Weerden GM, Mariani C (eds) Solanaceae V: advances in taxonomy and utilization. Nijmegen University Press, pp 85-96

Dice LR (1945) Measuring of the amount of ecologic association between species. Ecology 26:297-302

Edmonds JM (1979) Biosystematics of Solanum L., section Solanum (Maurella). In: Hawkes JG, Lester RN, Skelding $\mathrm{AD}$ (eds) The biology and taxonomy of the Solanaceae. Linnean Society Symposium Series (7), London Academic Press, pp 529-547

El Rabey HA, Badr A, Schäfer-Pregl R, Martin W, Salamini F (2002) Speciation and species separation in Hordeum L. (Poaceae) resolved by discontinuous molecular markers. Plant Biol 4:1-9

Felsenstein J (1985) Confidence limits on phylogenies: an approach using the bootstrap. Evolution 39:783-791

Gottlieb LD (1977) Electrophoretic evidence in plant systematics. Ann Missouri Bot Gard 64:161-180

Hammond DH (1979) Growth regulator interactions on morphogenesis in Solanum species. In: Hawkes JG, Lester RN, Skelding AD (eds) The biology and taxonomy of the Solanaceae. Linnean Society Symposium Series (7), London Academic Press, pp 357-369

Hawkes JG, Smith P (1965) Continental drift and the age of angiosperm genera. Nature 207:48-50

Heiser C (1971) Notes on some species of Solanum (section Leptostemonum) in Latin America. Baileya 18:59-65

Heiser C (2001) Interspecific hybridization and the improvement of the Naranjilla (Solanum quitoense). In: van den Berg RG, Barendse GWM, van der Weerden GM, Mariani C (eds) Solanaceae V: advances in taxonomy and utilization. Nijmegen University Press, pp 307-310

Heiser C, Anderson G (1999) "New" Solanums. In: Janick J (ed) Perspectives on new crops and new uses. Am Soc Hort Science Press, Alexandria, pp 379-384

Isshiki S, Okubo H, Fujieda K (1994) Phylogeny of eggplant and related Solanum species constructed by allozyme variation. Sci Hort 59:171-176

Isshiki S, Uchiyama T, Tashiro Y, Miyazaki S (1998) RFLP analysis of a PCR-amplified region of chloroplast DNA in eggplant and related Solanum species. Euphytica 102:295-299

Kardolus JP, van Eck HJ, van der Ber RG (1998) The potential of AFLPs in biosystematics: a first application in Solanum taxonomy (Solanaceae). Plant Syst Evol 210:87-103

Karihaloo JL, Gottlieb LD (1995) Allozyme variation in the eggplant, Solanum melongena L. (Solanaceae). Theor Appl Genet 90:578-583

Karihaloo JL, Brauner S, Gottlieb LD (1995) Random amplified polymorphic DNA variation in the eggplant, Solanum melongena L. (Solanaceae). Theor Appl Genet 90:767-770

Karihaloo JL, Kaur M, Singh S (2002) Seed protein diversity in Solanum melongena $\mathrm{L}$. and its wild and weedy relatives. Genet Res Crop Evol 49:533-539

Lester RN (1986) Taxonomy of scarlet eggplants, Solanum aethiopicum L. Acta Hort 182:125-132

Lester RN, Hasan SMZ (1990) The distinction between Solanum incanum L. and Solanum insanum L. (Solanaceae). Taxon 39:521-523

Lester RN, Hasan SMZ (1991) Origin and domestication of the brinjal eggplant, Solanum melongena, from Solanum incanum, in Africa and Asia. In: Hawkes JG, Lester RN, Nee M, Estrada N (eds) Solanaceae III: taxonomy-chemistry-evolution. Royal Botanical Gardens Kew, London, pp 369-387

Linnaeus C (1753) Species plantarum 1:184-188, Stockholm

Lynch M, Milligan BG (1994) Analysis of population genetic structure with RAPD markers. Mol Ecol 3:91-99

Mace ES, Lester RN, Gebhardt C (1999) AFLP analysis of genetic relationships among the cultivated eggplant, Solanum melon- 
gena L., and wild relatives (Solanaceae). Theor Appl Genet 99:626-633

Madhavadian P (1968) Chromosome numbers in South Indian Solanaceae. Caryologia 21:343-347

Nee M (1979) Pattern in biogeography in Solanum, section Acanthophora. In: Hawkes JG, Lester RN, Skelding AD (eds) The biology and taxonomy of the Solanaceae. Linnean Society Symposium Series (7), London Academic Press, pp 569-580

Nee M (1991) Synopsis of Solanum section Acanthophora: a group of interest for Glycoalkaloids. In: Hawkes JG, Lester RN, Nee M, Estrada N (eds) Solanaceae III: taxonomy-chemistryevolution. Royal Botanical Gardens Kew, London, pp 257-266

Nei M, Li WH (1979) Mathematical model for studying genetic variation in terms of restriction endonucleases. Proc Natl Acad Sci USA 76:5269-5273

Page RDM, Holmes EC (1998) Genes in populations. In: Page RDM, Holmes EC (eds) A phylogenetic approach. Molecular evolution. Blackwell Science, pp 89-134

Patterson C, Williams DM, Hunphries CJ (1993) Congruence between molecular and morphological phylogenies. Annu Rev Ecol Syst 24:153-188

Rodriguez JM, Berke T, Engle L, Nienhuis J (1999) Variation among and within Capsicum species revealed by RAPD markers. Theor Appl Genet 99:147-156

Rouppe van der Voort JNAM, van Zandvoort PM, van Eck HJ, Folkertsma RT, Hutten RCB, Braaistra J, Gommers FJ, Jacobsen E, Helder J, Bakker J (1997) Use of allele specificity of comigrating AFLP markers to align genetic maps from different potato genotypes. Mol Gen Genet 255:438-447

Saitou N, Nei M (1987) The neighbour-joining method: a new method for reconstructing phylogenetic trees. Mol Biol Evol $4: 406-425$

Sakata Y, Lester RN (1994) Chloroplast DNA diversity in eggplant (Solanum melongena) and its related species $S$. incanum and $S$. marginatum. Euphytica 80:1-4

Sakata Y, Nishio T, Matthews PJ (1991) Chloroplast DNA analysis of eggplant (Solanum melongena) and related species for their taxonomic affinity. Euphytica 55:21-26
Seithe A, Anderson GJ (1982) Hair morphology and the relationships of species in Solanum sect. Basarthum. Plant Syst Evol 139:229-256

Skroch PW, Nienhuis J, Beebe S, Tohme J, Pedraza F (1998) Comparison of Mexican common bean (Phaseolus vulgaris L.) core and reserve germplasm collections. Crop Sci 38:488-496

Studier JA, Keppler KJ (1988) A note on the neighbour-joining algorithm of Saitou and Nei. Mol Biol Evol 5:729-731

Van de Peer Y, de Wachter Y (1994) TRECON for Windows: a software package for the construction and drawing of evolutionary trees for the Microsoft Windows environments. Comput Appl Biosci 10:569-570

Vavilov NI (1951) The origin, variation, immunity and breeding of cultivated plants. Chron Bot 13:1-364

Vos P, Hogers R, Bleeker M, Reijans M, van de Lee T, Hornes M, Frijters A, Pot J, Peleman J, Kuiper M, Zabeau M (1995) AFLP: a new technique for DNA fingerprinting. Nucleic Acids Res 23:4407-4414

Weir BS (1996) Genetic data analysis II. Sinauer Associates, Massachusetts

Whalen MD (1979) Speciation in Solanum, section Androceras. In: Hawkes JG, Lester RN, Skelding AD (eds) The biology and taxonomy of the Solanaceae. Linnean Society Symposium Series (7), London Academic Press, pp 581-596

Whalen MD (1984) Conspectus of the species group in Solanum subgenus Leptostemonum. Gentes Herb 12:179-282

Whalen MD, Caruso E (1983) Phylogeny in Solanum sect. Lasiocarpa (Solanaceae). Congruence of morphological and molecular data. Syst Bot 8:369-380

Whalen MD, Costich D, Heiser C (1981) Taxonomy of Solanum section Lasiocarpa. Gentes Herb 12:41-129

Zabeau M, Vos P (1993) Selective restriction fragment amplification: a general method for DNA fingerprinting. European Patent Office, publication 0534858 A1 